\title{
The burnout patient
}

Stephen M. Sergay, MBBCh

Neurology: Clinical Practice August 2018 vol. 8 no. 4 346-348 doi:10.1212/CPJ.0000000000000482
Correspondence

Dr. Sergay

sergay1@me.com

\begin{abstract}
Physician and patient experiences of health care delivery are inextricably intertwined. Accelerating physician burnout has reached epidemic proportions in the United States. In parallel, health care has become a different experience for our patients. As a practicing neurologist over the last 40 years, I have observed changes in the expectations of colleagues and patients, whose feelings and concerns continually educate me. While I am not alone in advocating for intervention in current health care delivery methodology, not all are convinced. In discussing the repercussion of the "burnout patient," I seek to amplify the groundswell for change.
\end{abstract}

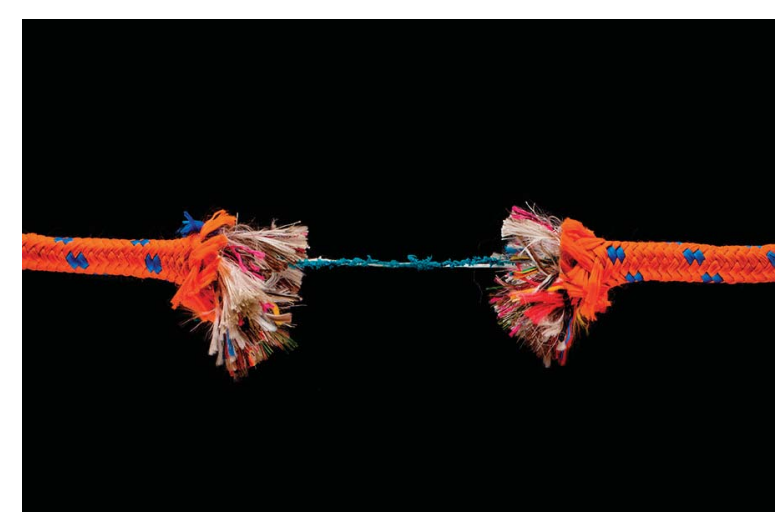

Words are the most powerful drug used by mankind. ${ }^{1}$

$$
\text { —Rudyard Kipling }
$$

A seldom mentioned consequence of increasing physician burnout ${ }^{2}$ is its inevitable effect on our patients. As a lifelong caregiving doctor, who currently dispenses private practice outpatient neurology care in the United States, I have come to recognize increasing levels of patient dissatisfaction. Patient satisfaction surveys are often used as metrics of patient contentment. Though surveys may reveal a patient's interpretation of a health care experience, the true value of this instrument is specious. ${ }^{3}$ Are there other methods that can reveal patient contentment? How do I know patients are disaffected? I actively listen to my patients and my colleagues-they are my focus groups.

\section{The patient's voice}

Our patients are becoming disillusioned about their caregivers and have dampened expectations for the care they receive. Their doctor no longer seems personally involved. Many patients feel helpless and bear a sense of defeat and resignation. Why, they ask, do we have to cope with both illness and care quality anxiety? My patients often recognize pursuit of efficiency over effectiveness. They complain their doctor is harried, their care hurried, mechanical, and lacking in humanity. They miss eye contact with their doctor, literally and figuratively. Their caregiver does not take the necessary time to know them as a person with an illness rather than as "a disease," to understand their experiences, anxieties, and preconceptions, all of which may dictate their receptivity to care approaches and methods. They decry the absence of discussion and explanation. They perceive the increased risk of their diagnosis being missed or delayed by regimented care delivery and that this often leads to unnecessary testing and its product: increased cost. They see their caregiver being sidetracked by recordkeeping and
RELATED ARTICLE

\section{Editorial}

Patients are harmed by physician burnout

Page 279 
Our patients are becoming disillusioned about their caregivers and have dampened expectations for the care they receive.

administrative requirements. They fear their hospital care may be suboptimal without an advocate.

When I discussed with a patient that her condition was irremediable but stable and that only infrequent visits were necessary, she exclaimed: "I need your reassurance. Don't you recognize the importance and value of this?" An older patient, ex-entrepreneur, when observing my administrative and recordkeeping tasks performed during his evaluation, asked me: "What have you done so wrong to deserve this recrimination: who is angry with you?" And another, a patient with Parkinson disease, requested an emergency evaluation for overwhelming dyskinesias not related to medication dose or timing. She was atypically anxious and for good reason. She recovered to her baseline after 20 minutes of discussion and reassurance, efficient and effective but nonmeasurable methods of care.

\section{The physician's voice}

I asked a group of caregiver physicians, nurse practitioners, and physician assistants, in their mid to late 30s, "What do you most look forward to when you come to work in the morning"? I was astonished when some responded: "A patient not showing up," a reaction to the meager time allotment for the encounter and the "tightness" of their schedules. I have heard older doctors blame the young for being too focused on "what's in it for them" and that they are "technicians and not humanists," while younger physicians blame their seniors for being "absent from the helm" when health care delivery changed. I have heard medical school professors acknowledge, with a shrug, that residents are required to sacrifice their evening reading time to complete that day's patient care documentation.

Rules and regulations designed to discourage expedience and earnings over quality care may inadvertently expose opportunities for human frailty, including perverse incentives and moral hazard. Doctors are incentivized to choose less challenging patient problems that require less effort and to spend insufficient time to explore the patient's complaints fully or provide emotional support. As they become increasingly disillusioned, some change their field or retire early. This has become systemic. When I have asked retired caregiving physicians in many disease fields if they miss their careers, many respond: "Mostly, I miss my patients," perhaps revealing drivers of their retirement decision are unrelated to their patient connection. The medical preceptor at a major teaching institution, on my daughter's first day of a summer pre-medical school clerkship, welcomed her by stating she should "reassess her plans for medical school" as medicine was a career in decline.

\section{Restoration of the patient-physician relationship}

Fundamental behavioral characteristics, or virtues, ${ }^{4}$ required of the physician in the relationship between the physician and ill patient, while necessary for effective health care planning, teaching, and delivery, are missing from the new quality assessment models. Innovations in health care delivery, designed to circumvent physician error and malfeasance, are not balanced by inclusion of components essential to patient care and physician fulfillment. Caregiving physicians must live by unequivocal ethical standards: shortcuts and deviations from our purpose risk pain, suffering, and perhaps death, in real time, while present-day measures focus more on technical and fiscal outcomes.

Current US care planning outcomes including efficiency, effectiveness, and cost-saving are laudable, but do not acknowledge the breadth of patient need, a more substantial physician motivator than promise of rewards and threat of penalties. I mourn lack of emphasis on pragmatic, in-depth doctoring performed at the bedside, where thoughtful dialogue leads to informed patient-specific diagnostic methodology and therapeutic management. Collection of data and electronic health records may add value, but the emotional connection with unwell, anxious individuals defies linearity, challenging creation of metrics. Health care often calls for human judgement and expert opinion, which proponents of precision medicine deride as untrustworthy and immeasurable. Yet when deployed appropriately, human judgement and expert opinion facilitate, rather than impede, thinking. Their value is in their subjectivity. Let us invite our patients to talk with us and then listen to them. We will be rewarded and honored by trust, a diminishing quality in today's society at large. ${ }^{5}$ Mutual trust is the foundation of the physicianpatient relationship, a source of self-respect and dignity for both.

\section{Mutual trust is the foundation of} the physician-patient relationship, a source of self-respect and dignity for both. 


\section{Conclusions and future directions}

Identification and management of negative consequences of current policy ${ }^{6}$ is not enough. We must look beyond others' reactions and turn inwards to define qualities we caregiving physicians consider elemental to patients and ensure their incorporation into care delivery. There is no greater opportunity for high-quality care delivery and dissipation of patient burnout than a caregiver given the optimized opportunity for self-actualization and fulfillment. ${ }^{7,8}$ I eagerly anticipate the time when caregiver physicians design contemplative care delivery practices with outcome metrics to confirm their value to patient well-being, quality health, and economic outcomes, beyond those leveraged by financial reward or punishment.

Neuroscience research, neuroscience teaching, and the practice of neurology per se have never been more exciting. When physician burnout is diminished, the choice of a career in neurology will become more desirable. ${ }^{9}$ We have a responsibility to ourselves and our patients. Let us not abandon the lifelong virtues of a career in medicine we inherited from our predecessors. Let us be inspired and motivated by a sense of wonder at humanity and medical science. Many claim that restoration of medical practice according to our codes of character and medical behavioral ethics is impossible. I contest that. Rebalancing can begin by ensuring the voices of the patient and caregiving doctor in health care deliberations are heard.

\section{Author contributions}

S. Sergay: drafting/revising the manuscript, study concept or design, analysis or interpretation of data, acquisition of data.

\section{Study funding}

No targeted funding reported.

\section{Disclosure}

S. Sergay is the managing partner of Tampa Neurology Associates and partner in Axiom Clinical Research. $\mathrm{He}$ is on an advisory board for Adamas. Over the last 2 years, Axiom has contracted with the following companies to perform clinical research: Accera, Avanir, Axovant, Bayer, Biogen Idec, Biorasi/Osmotica, CAMMS, Dart Neuroscience, Eisai, Sanofi/Genzyme, Eli Lilly, Genentech/ Roche, GlaxoSmithKline, Hoffman LaRoche, MAP Pharmaceuticals, Novartis, Opexa Therapeutics, Pfizer, Inc., Receptos, SanofiAventis, Suven, Tau Rx, WWCT/Neurotrope, and Xenoport, Inc. Full disclosure form information provided by the authors is available with the full text of this article at Neurology.org/cp.

Received December 27, 2017. Accepted in final form April 6, 2018.

\section{References}

1. Kipling R. Huntarian ovation, "surgeons and the soul": annual dinner, Royal College of London. In: A Book of Words: Selection of Speeches and Addresses Delivered Between 1906 and 1927. New York: Macmillan; 1928.

2. Parks T. Report reveals severity of burnout by specialty. AMA Wire 2017:1-10. Available at: wire.ama-assn.org/life-career/report-reveals-severity-burnout-specialty. Accessed July 6, 2017.

3. Junewicz A, Younger S. Patient-satisfaction surveys on a scale of 0-10: improving health care or leading it astray? Hastings Cent Rep 2015;1:43-51. Abstract.

4. Pellegrino ED, Thomasma DC. The Virtues in Medical Practice. Oxford: Oxford University Press; 1993:65-159.

5. Cass C. Poll: Americans don't trust one another. In: USA today [online]. Available at: usatoday.com/story/news/nation/2013/11/30/poll-americans-dont-trust-one-another/3792179/. Accessed December 23, 2013.

6. Miyasaki J, Rheaume C, Gulya L, et al. Qualitative study of burnout, career satisfaction and well-being among US neurologists in 2016. Neurology 2017;89:1730-1738.

7. Sergay SM. Charter on physician professional flourishing, Neurology 2016:87: 2259-2265.

8. Maslach C, Schaufeli WB, Leiter MP. Job burnout. Annu Rev Psychol 2001;52 397-422.

9. Khan J, Bernat JL. Preventing burnout increases the desirability of neurology as a career. Neurology 2017;89:1658-1659.

\section{Practical Implications}

Neurology ${ }^{\otimes}$ Clinical Practice is committed to providing clinical insights helpful to neurologists in everyday practice. Each Full Case includes a "Practical Implications" statement, a pearl of wisdom for the practicing clinician. 


\title{
Neurology Clinical Practice
}

\author{
The burnout patient \\ Stephen M. Sergay \\ Neurol Clin Pract 2018;8;346-348 Published Online before print June 18, 2018 \\ DOI 10.1212/CPJ.0000000000000482
}

This information is current as of June 18, 2018

\section{Updated Information \& Services}

References

Citations

Permissions \& Licensing

Reprints including high resolution figures, can be found at:

http://cp.neurology.org/content/8/4/346.full.html

This article cites 5 articles, 0 of which you can access for free at: http://cp.neurology.org/content/8/4/346.full.html\#\#ref-list-1

This article has been cited by 3 HighWire-hosted articles: http://cp.neurology.org/content/8/4/346.full.html\#\#otherarticles

Information about reproducing this article in parts (figures,tables) or in its entirety can be found online at: http://cp.neurology.org/misc/about.xhtml\#permissions

Information about ordering reprints can be found online: http://cp.neurology.org/misc/addir.xhtml\#reprintsus

Neurol Clin Pract is an official journal of the American Academy of Neurology. Published continuously since 2011, it is now a bimonthly with 6 issues per year. Copyright ( 92018 American Academy of Neurology. All rights reserved. Print ISSN: 2163-0402. Online ISSN: 2163-0933.

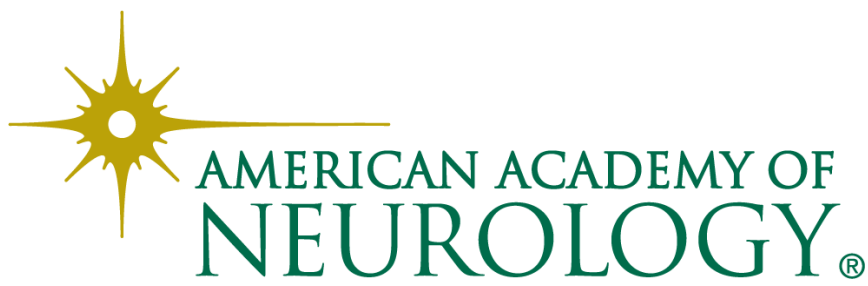

